\title{
Usual Source of Treatment in Northeast India
}

\author{
Pralip Kumar Narzary
}

Received: 30112014 / Accepted: 22122014 / Published online: 30062015

(c) 2015 Faculty of Geography UGM and The Indonesian Geographers Association

\begin{abstract}
The northeast India comprises of eight states with great socio-cultural and geo-political diversity. The region is home of several ethnic groups, quite sensitive to illegal immigration and insurgency infected. Thus, an attempt is made to understand how the health seeking behavior varies under such diversity. For the study National Family Health Survey 2005-06 data have been used. Appropriate bi-variate and multi-variate statistical techniques have been applied to draw meaningful conclusions. In entire northeast India, the percentage of households who usually avail treatment from public healthcare centres is much higher than the national average. Dependence on public healthcare centres is highest in Mizoram and Sikkim, followed by Arunachal Pradesh, whereas it is lowest in the state of Nagaland. In all the states main reasons for usually not seeking treatment from public healthcare centres is 'no facility nearby', 'poor quality of care' and 'long waiting time'.
\end{abstract}

Keywords: Healthcare centre; health seeking behavior; treatment

\begin{abstract}
Abstrak Di timur laut India terdiri dari delapan negara dengan keragaman sosial budaya dan geo-politik yang besar. Wilayah ini merupakan rumah dari beberapa kelompok etnis, cukup sensitif terhadap imigrasi ilegal dan pemberontakan terinfeksi. Oleh karena itu sebuah usaha dilakukan untuk memahami bagaimana cara mencari variasi perilaku kesehatan dalam keargaman tersebut. Penelitiann ini menggunakan data Survei Kesehatan Keluarga Nasional 2005-06. Penarikan kesimpulan diterapkan berdasarkan teknik statistik bi-variate dan multi-variate. Di seluruh timur laut India, persentase rumah tangga yang biasa memanfaatkan perawatan dari pusat kesehatan masyarakat jauh lebih tinggi dari rata-rata nasional. Ketergantungan pada pusat kesehatan masyarakat yang tertinggi berada di Mizoram dan Sikkim, kemudian diikuti oleh Arunachal Pradesh, sedangkan hasil yang terendah di negara bagian Nagaland. Alasan utama dari delapan negara di timur laut India untuk biasanya tidak mencari pengobatan dari pusat kesehatan masyarakat adalah 'tidak ada fasilitas di dekatnya', 'rendahnya kualitas pelayanan' dan 'waktu tunggu yang lama'.
\end{abstract}

Kata kunci: pusat kesehatan; pencarian perilaku kesehatan; pengobatan

\section{Introduction}

Behavior of human being relating to treatment and health is a complex phenomenon. Each individual community practices their particular way of lives and perceives healthcare services differently from others [Chin and Noor, 2014], thereby respond differently. For instance, in tribal communities, healthcare seeking behavior is motivated by culturally specific beliefs about which practitioners to consult with regarding issues of health [Sundararajan et. al., 2013]. Similarly, among the Boro tribe of Assam, initial source of treatment depends on the perception and believe of the cause of health problem [Narzary and Narzary, 2005]. For certain diseases/health people may have very strong faith in traditional medicine. But for other diseases/health problems they may rely on modern medicine. Such differential faith in the different source

Pralip Kumar Narzary

Dept of Population Studies, Fakir Mohan University, Vyasa Vihar, Nuapadhi, Balasore - 756 020, Odisha, India

Email:pralipkn@gmail.com of treatment must have been inherited through long period of practical experiences [Narzary and Narzary, 2005].

Mere existence of healthcare services does not automatically lead to their utilization. Even while ill, some of the individuals do not seek treatment because they perceive their illness to be less severe, or suffer from financial constraints [Patel et. al., 2010; Keith, 2004]. Financial constraints may be perceived on anticipated cost of treatment [Patel et. al., 2010; Pandey 2010]. The preference for particular source or system of treatment depends upon the severity of illness, availability, accessibility, affordability and acceptability of healthcare services [Narzary, 2012: 56]. Its utilization also depends upon quality [Jain et. al., 2006; Neelima \& Reddy, 2006], availability of drugs and competence of staff [Fomba et. al., 2010]. Further, some believe that suspected heath problem (tuberculosis) can be easily detected by doctors from government health center; however same can be cured mainly by private practitioner doctors [Narzary and Narzary, 2005]. One of the reasons for giving preference to private 
healthcare facilities might be its availability at the door step. Whereas, inadequacy of facilities/services in government setup and unclean premises, unfriendly behavior of staff and doctors towards patient, and lack of faith in government doctors are some of the reasons for not adopting public healthcare facilities [Patel et. al., 2010].

The differentials in belief, attitude or preference for particular source of treatment - government / public or private healthcare facilities - may be perceived currently, gained from past experience or heard from others' mouth. It is apparent that the availability, accessibility, affordability, acceptability and quality of healthcare facilities, and hosts of individual, household or socio-cultural constraints affects the utilization of healthcare services, in other words the treatment seeking behavior of a community. Thus, in this paper an attempt is made to understand the health seeking behavior of households, especially the preference for particular source of healthcare centre and reasons associated with it, under the diverse socio-cultural and geo-political settings.

\section{The Methods}

Data for the present study comes from the National Family Health Survey 2005-06 (NFHS-3). The survey was conducted all over India during the year 2005-06, and in the region it was conducted during December 2005 to August 2006 [IIPS and Macro International, 2007]. An important objective of the survey has been to provide national and state estimate of various indicators like fertility, mortality, health etc. [IIPS and International Macro, 2007]. Hence, samples are drawn through systematic procedure and are true representative of the state. In the region, the sample size varies from 1,513 in Mizoram to 3,886 in Nagaland. The total sample size of northeast as a whole is 19, 211 households.

In the initial stage of analysis, bi-variate cross tabulation is done along with chi square test to see if there is any possible relationship between the independent and dependant variable. Bi-variate graphical presentation is also made to see the association between the variables. In the later stage, binary logistic regression, one of the multi-variate statistical techniques, has been applied to draw meaningful conclusions. The entire data analyses are done in statistical software package SPSS 20.

Dependant variables: National family health survey administered a question 'when members of your household get sick, where do they generally go for treatment?'. The possible responses were pre-coded and they are categorized into 'government / public healthcare centre' and 'private healthcare centre' in the present study. Following this question, a question was asked 'why don't members of your household generally go to a government facility when they are sick? In response to this question following five multiple choice options were given. They were [1] 'no nearby facility', [2] 'facility timing not convenient', [3] 'health personnel often absent', [4] 'waiting time too long', [5] 'poor quality of care', and additional - [6] 'other' category.

Independent variables: [1] Place of residence is provided as 'urban' and 'rural' and used as it is. [2] One of the bases of categorizing population in India is - 'scheduled caste', 'scheduled tribe', 'other backward caste' and 'none of them'. NFHS-3 had this question and had these four options. But in the present study it is regrouped into 'scheduled tribe' and 'not scheduled tribe'. [3] Question on religion, although had several options, it is regrouped into 'Hindu', 'Christian' and remaining are grouped into 'Others' category. [4] Based on wealth index, population is divided into five wealth quintiles. At the national level, each category contains $20 \%$ of the sample, but it may not be true at the state level. This variable is used as it is given. [5] Sex of the head of the household is given as 'male headed' and 'female headed'. [6] Age of the head of the household although is given in single years, it is recoded into five suitable categories as follows 'Upto 30,' ' 31 - 40, '41 50 ', '51 - 60' and ' 61 \& above'.

North-east India is comprised of eight sister states, namely Arunachal Pradesh, Assam, Manipur, Meghalaya, Mizoram, Nagaland, Sikkim and Tripura. As the name suggests, the region occupies the northeastern corner of the country (Figure1). Seven out of eight states are geographically connected to each other, but Sikkim is not (Figure 2). Further, the six states have a common gateway to reach mainland India, which is Assam. Sikkim and Assam have other gateway that is West Bengal. As per the 2011 Census, the total population of the region is about $3.8 \%$ of the total population of India. In terms of population size, Assam is the largest state, which contributes about $68 \%$ of the regional population and $2.58 \%$ of the national population, whereas Sikkim is the smallest state (table: 1). Arunachal Pradesh has a density of only 17 persons per square KM. Only Assam (with density of 398) exceeds national average density (382), whereas others have much lower density. The region has pretty high literacy rate. Except Arunachal Pradesh (66.95\%), all the states have literacy rate much above the national average $(74.04 \%)$. The region is home to plenty of tribal communities or indigenous population. Except Assam, Manipur and Tripura, other states are tribal dominated state. Mizoram, Nagaland and Meghalaya are Christian dominated states. The sex ratio in the region, especially the tribal sex ratio, is in favor of female population. Overall, the population of the region is more inclined towards the western culture rather than Indian, which may be due to the adoption and or influence of Christianity. The region is also extremely sensitive to illegal immigration and migration from Indian mainland. Further, the regions infected by several insurgent groups. Almost all of the states are having several insurgent groups, fighting for various causes.

Geographically, the region stretches between latitude: $21.57^{\circ} \mathrm{N}-29.30^{\circ} \mathrm{N}$, and longitude: $88^{\circ} \mathrm{E}-$ 
$97.30^{\circ} \mathrm{E}$, covering a geographical area of about $7.9 \%$ of the landmass of India. Although she contributes only about $3.8 \%$ of population to the nation, but it occupies an extremely strategic position, due to the international border. The region is surrounded by countries like China, Nepal, Bhutan, Myanmar and Bangladesh. International border of the region forms nearly $90 \%$ of India's international boundaries. The region is also key for developing trade and commerce relationship with other South-East Asian nations like Myanmar, Thailand, Vietnam etc. As per NEDFi 2009 data, about $54 \%$ of geographical area of the region is covered with forest, which varies from $75.59 \%$ in Mizoram to only

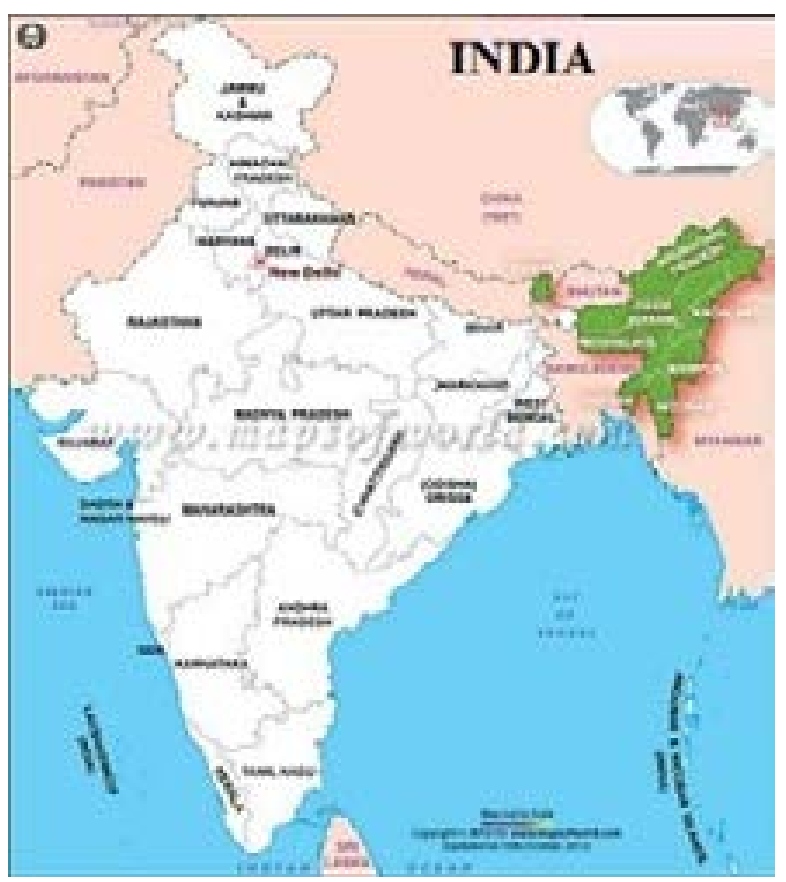

Figure1. Map of India highlighting Northeast
$42.34 \%$ in Meghalaya (table: 1). The region is also protected by the mighty Himalaya and about $70 \%$ of landmass of the region is either mountainous, hilly or plateau. The Himalaya Mountain not only protects the region from cold winter breeze blowing from the north, but also provides protection against invasion. The great Brahmaputra River flows from northeast corner to southwest corner, which is also a potential gateway of having international water transport network with Bangladesh and other countries. However, this very river is also considered to be facilitating illegal immigration to the region and other parts of the nation. Further, this river can be considered as the sorrow of Assam due to

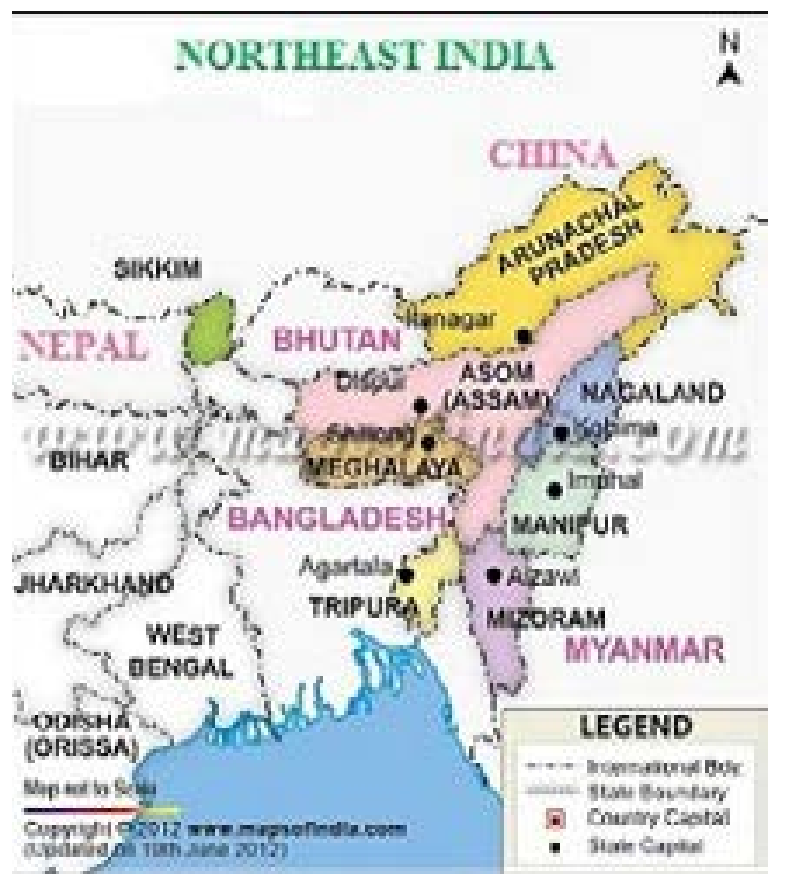

Figure 2. Map of Northeast India highlighting various states within the region

Table. 1 Basic demographic and geographical facts of Northeast India

\begin{tabular}{lrrrrrrr}
\hline \multicolumn{1}{c}{ States } & $\begin{array}{c}\text { Geog. area (in } \\
\text { sq KM) } 1\end{array}$ & $\begin{array}{c}\text { \% of forest } \\
\text { area2 }\end{array}$ & $\begin{array}{c}\text { Total } \\
\text { Population1 }\end{array}$ & $\begin{array}{c}\text { \% of ST } \\
\text { population1 }\end{array}$ & $\begin{array}{c}\text { Density of } \\
\text { population1 }\end{array}$ & $\begin{array}{c}\text { Literacy } \\
\text { rate1 }\end{array}$ & $\begin{array}{c}\text { Sex } \\
\text { ratio1 }\end{array}$ \\
\hline Arunachal & 87,743 & 80.5 & $13,82,611$ & 68.8 & 17 & 66.95 & 920 \\
Assam & 78,438 & 35.3 & $311,69,272$ & 12.4 & 398 & 73.18 & 954 \\
Manipur & 22,327 & 76.5 & $27,21,756$ & 35.1 & 115 & 79.85 & 987 \\
Meghalaya & 22,429 & 77.0 & $29,64,007$ & 86.1 & 132 & 75.48 & 986 \\
Mizoram & 21,081 & 90.7 & $10,91,014$ & 94.4 & 52 & 91.58 & 975 \\
Nagaland & 16,579 & 80.3 & $19,80,602$ & 86.5 & 119 & 80.11 & 931 \\
Sikkim & 7,096 & 47.3 & $6,07,688$ & 33.8 & 86 & 82.20 & 889 \\
Tripura & 10,486 & 76.0 & $36,71,032$ & 31.8 & 350 & 87.75 & 961 \\
\hline
\end{tabular}

Source: 1: Census of India 2011, 2: NEDFi 2009 
its recurrent floods causing great destructions every year.

\section{Result and Discussion}

Developmental activity led to the unequal distribution of resources across the communities and regions [Bijukumar, 2013] in Northeast India. Hence, an apparent rural - urban differential in preference for the usual source of treatment is observed. About 60 percent of the urban households and as high as 77 percent of rural households reported the government healthcare facilities as the usual source of treatment (Table 2). This may be a pointer to the existing rural - urban differentials in distribution of healthcare infrastructures, capability of the urban households to pay for the private healthcare services, or differentials in reliance on private healthcare system.

Each individual community practices their particular way of lives and perceives healthcare services differently from others; of which these social dimensions of their lives ultimately exert impact on their well-beings [Chin and Noor, 2014]. In tribal communities, healthcare seeking behavior is motivated by culturally specific beliefs about which practitioners to consult with regarding issues of health [Sundararajan et. al., 2013]. There is a common believe that the tribals have more inclination towards the traditional way of life. Study also shows that majority of the tribals believe that 'one who can do hard work and is free from the influences of sprits is not sick'. Such beliefs have kept the tribes away from optimal utilization of various health service launched by the government from time to time [Bisai et. al., 2014]. But in preset study no apparent differential between tribals and non tribals in terms of accessing government healthcare centres is observed, but the result is statistically not significant. This may be because tribals in northeast India are relatively more developed than the tribals of other parts of India. Other study also suggests that different tribal groups in India are at different levels of development [Bisai et. al., 2014]. Human behavior is also greatly shaped by the religious believe, it is more so in terms of health problems. It is noticeable that in northeast India, religion plays a great role in matter relating to the treatment seeking behavior. It seems that dependence on government healthcare facilities is lesser among the Hindus, whereas it is highest among the Christians.

Economic status, along with socio-cultural belief and practices, also plays a great role in health seeking behavior, especially in preference for source

Table. 2 Percentage of households by usual source of treatment and background characteristics

\begin{tabular}{|c|c|c|c|c|}
\hline \multirow[t]{2}{*}{ Variable } & \multicolumn{2}{|c|}{ Usual source of treatment } & \multirow[t]{2}{*}{ Cases } & \multirow[t]{2}{*}{$\mathrm{X} 2$} \\
\hline & Govt. & Private & & \\
\hline Place of residence & & & & Sig. \\
\hline Urban & 59.4 & 40.6 & 7,809 & \\
\hline Rural & 77.0 & 23.0 & 11,402 & \\
\hline Not/ Scheduled Tribe & & & & Sig. \\
\hline Scheduled Tribe & 69.9 & 30.1 & 8,411 & \\
\hline Not - Scheduled Tribe & 69.8 & 30.2 & 10,800 & \\
\hline Religion & & & & NS \\
\hline Hindu & 70.4 & 29.6 & 8,532 & \\
\hline Christian & 66.7 & 33.3 & 7,105 & \\
\hline Others & 74.9 & 25.1 & 3,574 & \\
\hline Wealth index & & & & Sig. \\
\hline Poorest & 77.2 & 22.8 & 1,599 & \\
\hline Poor & 77.6 & 22.4 & 3,440 & \\
\hline Middle & 76.7 & 23.3 & 4,829 & \\
\hline Rich & 68.2 & 31.8 & 5,063 & \\
\hline Richest & 55.2 & 44.8 & 4,280 & \\
\hline \multicolumn{5}{|l|}{ Sex of household head } \\
\hline Male & 70.3 & 29.7 & 16,248 & Sig. \\
\hline Female & 67.7 & 32.3 & 2,963 & \\
\hline \multicolumn{5}{|l|}{ Age of household head } \\
\hline Upto 30 & 68.7 & 31.3 & 3,337 & Sig. \\
\hline $31-40$ & 67.4 & 32.6 & 5,001 & \\
\hline $41-50$ & 70.1 & 29.9 & 4,387 & \\
\hline $51-60$ & 70.8 & 29.2 & 3,550 & \\
\hline $61 \&$ above & 74.0 & 26.0 & 2,936 & \\
\hline Total & 69.9 & 30.1 & 19,211 & -- \\
\hline
\end{tabular}

Note: Sig.: significant; NS: not significant 
of treatment. This is related to the capability to pay for the services. It may happen that there is no sociocultural restriction on accessing modern healthcare facilities, but due to the economic incapability they are compelled to depend on traditional healer. In the present study it is observed that there is a link between the wealth index and the preference for the particular source of treatment. The percentage of household who reported government healthcare centres as the usual source of treatment gradually decreases by the improvement in the wealth index, on the other hand percentage of households seeking treatment from private healthcare centres increases. Other study also found that household's poverty status emerged as the major determinants of both health seeking behavior and heath care-expenditure [Ahmed et. al., 2005], also the utilization of maternal health care [Singh et al., 2012]. In Indian culture, behavior of an individual greatly depends on the characteristics of the head of the household. As the head takes most of the decisions either by consulting or without consulting the individual member of the household. In health seeking matter, it is found that compared to female headed households, more of the male headed households reported to seek treatment from government healthcare centres. It implies that reliance on private healthcare centres is more among the female headed households. It may be because given a chance to make decision, women are more particular about health problems and prefer to visit private healthcare centres for getting better quality treatment. While searching for relationship between age of household head and dependency on particular source of healthcare centres, almost a straight positive relationship is noted. As the age increases, percentage of households reporting to visit government healthcare centres for usual treatment also increases. It may be because the older people are not much aware about the modern healthcare requirements, and also not familiar with the system, hence rely on government healthcare centres. Whereas, they may be more accustomed to government healthcare centres, and thereby prefer to visit them.

It is found that percentage of households who usually seek treatment from public healthcare centres is pretty high in the states of Sikkim, Mizoram and Arunachal Pradesh (Figure 3). In these states more than 80 percent of the households reported to seek treatment from public healthcare facilities. These states are topographically either mountainous or hilly regions. In four other states namely Tripura, Manipur, Assam and Meghalaya, 60 - 80 percent usually relies on government healthcare facilities. This means that remaining one-fifth of the households in these states rely on private healthcare facilities. But in Nagaland only half of the total households depend on government health care facilities. Overall, almost two-third of northeast Indian households, but only about one-third of the Indian households usually seeks treatment from government healthcare facilities. This clearly indicates that dependence on government healthcare facilities is much higher in northeast India. It is more than twice that of national average. This may not imply the high quality of government healthcare centres, but it is the absence of private healthcare centres in the rural areas, and its concentration only in the cities. One of the reasons for absence of private healthcare centres in the rural areas and small towns may be due to the wide prevalence of insurgency, poor transportation facility and difficult physiographic features in the region.

From multi-variate statistics result it is seen that compared to Arunachal Pradesh, households from the states of Mizoram and Sikkim are more likely to report government healthcare centres as their usual source of treatment, whereas it is opposite for the remaining states and the result is statistically significant. For Mizoram and Sikkim probability of availing healthcare services from government healthcare centres is three times that of Arunachal Pradesh. This result re-affirms the association seen from the bi-variate statistics. Result of binary logistic regression shows that compared to

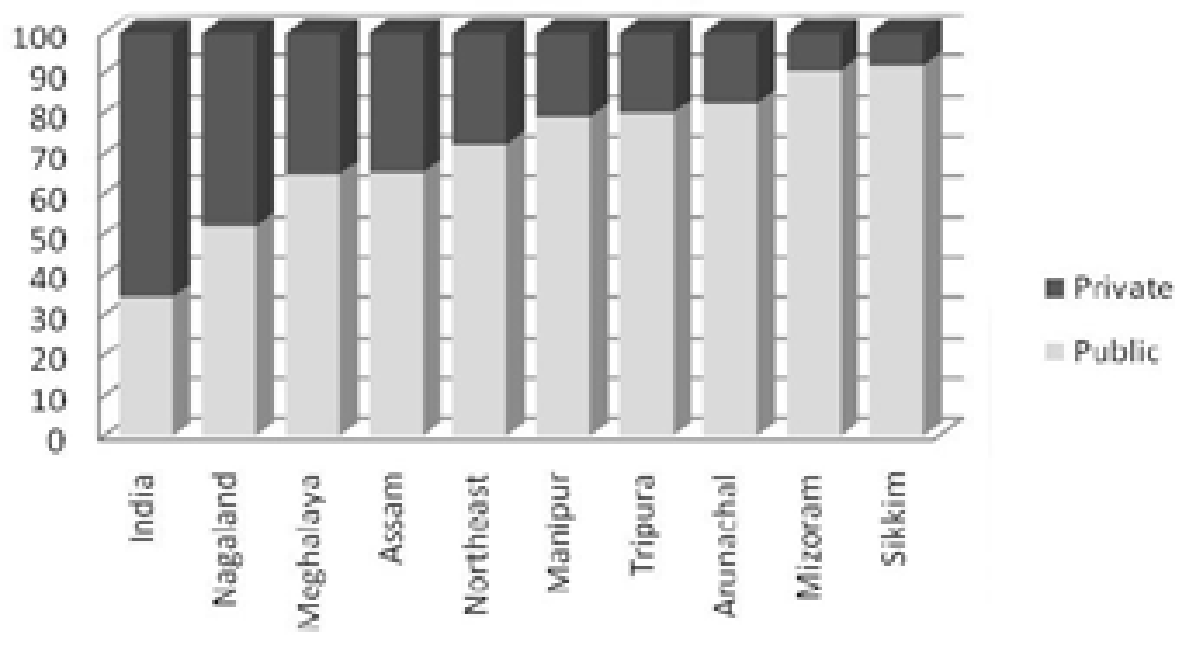

Figure 3. Percentage of Hoseholds by Usual Source of Treatment 
urban households, rural households are more likely to report government healthcare centres as the usual source of treatment (OR: 1.520; CI: 1.404 -1.645). This result is found to be statistically quite significant. This may be because of limited availability of private healthcare facilities in the rural areas, implying the compulsion to depend on the government healthcare facilities. There is an indication that compared to Hindu households, Christian households are more likely to prefer government healthcare centres, whereas household following other than Hindu and Christian religion are less likely to report government healthcare centres as their usual source of treatment. However, the result is not significant (Table 3 ).

The relationship between wealth index and usual source of treatment is statistically not significant for poor and middle quintile households, but it is significant for rich and richest quintiles. Compared to poorest households, rich and richest households are less likely to report government healthcare centres as the usual source of treatment. This may be because as the financial capacity of the household improves, people may prefer to visit private healthcare centres, rather than a government centre, may be to get better quality service. It is quite apparent that, other things being equal, female headed households are less likely to prefer the government heath care centre for the usual treatment. This may be because if women have control over household decision making, they would prefer to seek better quality healthcare services from the private healthcare providers. Unlike male counterpart, women may not hesitate to part away some resources for better health of the household members. With the increase in age of the household head, the probability of reporting government healthcare centres as usual source of treatment increases (OR: 1.007, CI: 1.004 - 1.009) and the result is statistically highly significant. This reaffirms the result of bi-variate statistics.

It is seen that compared to the national average, much higher percentages of households in northeast India reported government health care centres as the usual source of treatment. Now the pertinent question is why such a high percentage of the households in northeast India prefer private health care centres for their treatment. In Nagaland and Arunachal Pradesh more than half of the households, who usually seek treatment from private healthcare centres, says that it is because of 'no nearby facility' they do not go to government healthcare facilities (Table 4). The same reason is cited by 45 percent in Assam, 31 percent in Meghalaya, 29 percent in Manipur, and about 27 percent in Mizoram and Tripura. Interestingly, in Sikkim only six percent cited 'no nearby facility' as the reason for not availing healthcare from government healthcare centres. Slightly more than one-fifth expresses 'facility timing not convenient' as the reason in Arunachal, Tripura, Sikkim and Manipur. This reason is least cited in the states of Assam and Mizoram. Slightly more than 10 percent in the states of Meghalaya and Manipur says that 'health personnel are often absent', in all other states this is cited by less than 10 percent of the related samples. Hence, in northeast India as a whole 'no nearby facility' (41.9\%) is found to be main reason, followed by 'poor quality of service' $(37.7 \%)$ and 'waiting time too long'

Table. 3 Results of binary logistic regression.

\begin{tabular}{|c|c|c|c|c|c|}
\hline \multicolumn{6}{|c|}{ Dependant variable: Usual source of treatment: $1=$ govt; $0=$ pvt. } \\
\hline \multicolumn{2}{|c|}{ Independent variables } & \multirow[t]{2}{*}{ Beta } & \multirow[t]{2}{*}{ Exp. Beta } & \multicolumn{2}{|c|}{ Confidence interval } \\
\hline & & & & Lower & Upper \\
\hline State & $\begin{array}{l}\text { Arunachal } \\
\text { Assam } \\
\text { Manipur } \\
\text { Meghalaya } \\
\text { Mizoram } \\
\text { Nagaland } \\
\text { Sikkim } \\
\text { Tripura }\end{array}$ & $\begin{array}{l}1.000 \\
-1.144 \\
-0.234 \\
-1.018 \\
1.176 \\
-1.626 \\
1.161 \\
-0.478\end{array}$ & $\begin{array}{l}0.319^{* * *} \\
0.791^{* *} \\
0.361^{* * *} \\
3.241^{\star * *} \\
0.197^{\star * *} \\
3.194^{* * *} \\
0.620^{* * *}\end{array}$ & $\begin{array}{l}0.272 \\
0.672 \\
0.304 \\
2.559 \\
0.167 \\
2.595 \\
0.512\end{array}$ & $\begin{array}{l}0.373 \\
0.931 \\
0.429 \\
4.106 \\
0.231 \\
3.933 \\
0.750\end{array}$ \\
\hline Residence & $\begin{array}{l}\text { Urban } \\
\text { Rural }\end{array}$ & $\begin{array}{l}1.000 \\
0.419\end{array}$ & $1.520^{\star * *}$ & 1.404 & 1.645 \\
\hline Religion & $\begin{array}{l}\text { Hindu } \\
\text { Christian } \\
\text { Others }\end{array}$ & $\begin{array}{l}1.000 \\
0.004 \\
-0.050\end{array}$ & $\begin{array}{l}1.004 \\
0.952\end{array}$ & $\begin{array}{l}0.905 \\
0.861\end{array}$ & $\begin{array}{l}1.114 \\
1.052\end{array}$ \\
\hline Wealth index & $\begin{array}{l}\text { Poorest } \\
\text { Poor } \\
\text { Middle } \\
\text { Rich } \\
\text { Richest }\end{array}$ & $\begin{array}{l}1.000 \\
0.032 \\
-0.090 \\
-0.519 \\
-1.348\end{array}$ & $\begin{array}{l}1.032 \\
0.914 \\
0.595^{\star * *} \\
0.260^{* * *}\end{array}$ & $\begin{array}{l}0.891 \\
0.792 \\
0.515 \\
0.223\end{array}$ & $\begin{array}{l}1.196 \\
1.056 \\
0.688 \\
0.303\end{array}$ \\
\hline Sex of HH head & $\begin{array}{l}\text { Male } \\
\text { Female }\end{array}$ & $\begin{array}{l}1.000 \\
-0.129\end{array}$ & $0.879^{\star *}$ & 0.801 & \\
\hline Age of househol & (HH) head & 0.007 & $1.007^{\star * *}$ & 1.004 & 1.009 \\
\hline
\end{tabular}


(19.0\%). In the national level also although these are the three main reasons, but pattern is slightly different. The first main reason at national average is 'poor quality of care' $(57.7 \%)$, followed by 'no nearby facility' (46.8\%) and 'waiting time too long' (24.8\%). This difference may be attributed to the difference in topographical settings at aggregate level Table 5. This result suggests that the main reasons for not availing health care services from government health care centres in northeast India is similar to that of India as a whole. In urban areas 'poor quality of care', 'no nearby facility', and 'waiting time too long' are the three main reasons for not availing service from the government health care centres. In the rural areas the main reasons are 'no nearby facility', 'poor quality of care' and 'waiting time too long. This result implies that in rural areas, there is need to set up more government healthcare infrastructure, whereas in urban areas quality needs to be improved. Policy makers may look forward to tackle these problems to reduce the burden of health care on household.

An attempt is made to assess the composite number of reasons cited for not accessing government healthcare centres. In all the eight states, overwhelming percentage of samples cited only one reason (table: 5). It varies between 64 percent in Arunachal to as high as 89 percent in Mizoram. In the state of Mizoram, 89 percent cited only one reason, whereas remaining 11 percent cited two reasons. In Sikkim, 66 percent cited one reason, 31 percent cited two reasons and remaining 3 percent cited three reasons. Samples from Meghalaya, Assam and Tripura cited four reasons. But in the states of Arunachal, Manipur and Nagaland respondents mentioned five reasons. Overall, two-thirds of sample in Northeast India cited only one reason, about onefifth mentioned two reasons for not availing health care services from government healthcare centres.

\section{Conclusion}

Health seeking behavior depends on hosts of factors. Various socio-economic factors play role at the micro level. But, the geographical settings play vital role at the macro level. The topography of a region may hinder setting up of healthcare infrastructures, transport and communication network, etc. thus may affect the health seeking behavior of households. In northeast India, state/region, place of residence, wealth index, sex and age of the household head are some of the determining factors for reporting government healthcare centres as the usual source of treatment. Main cited reasons for usually not seeking treatment from the government healthcare centres are 'no nearby facility' followed by 'poor quality of care' and 'waiting time too long'. The shortage of healthcare infrastructure in the region is also highlighted in the Human Development Report of North East States [Government of India, 2011] it self. The report suggests that, for the North Eastern States having scattered and low density population the institutions need to be set up on the basis of habitation and not on population norms. This study further suggests that to improve the health seeking behavior of the region, information education and communication (IEC) relating to healthcare should be improved. Mere establishment of more healthcare infrastructure may not necessary lead to its utilization. For successful development and especially implementation of the IEC program, the great socio-cultural and geopolitical diversity of the region must also be taken into consideration.

Table. 4 Reasons for not availing treatment from public health care centres

\begin{tabular}{|c|c|c|c|c|c|c|c|c|c|}
\hline $\begin{array}{l}\text { Residence \& } \\
\text { States }\end{array}$ & [1] & {$[2]$} & {$[3]$} & {$[4]$} & [5] & {$[6]$} & [7] & {$[8]$} & Cases \\
\hline Residence & 37.9 & 18.8 & 8.0 & 23.0 & 38.7 & 0.2 & 0.2 & 7.1 & 3,164 \\
\hline \multicolumn{10}{|l|}{ States } \\
\hline Arunachal P & 51.3 & 25.1 & 6.5 & 18.2 & 36.0 & 0.0 & 0.0 & 6.4 & 277 \\
\hline Assam & 45.3 & 7.7 & 6.3 & 13.1 & 41.9 & 0.3 & 1.5 & 7.1 & 1,290 \\
\hline Sikkim & 6.3 & 20.5 & 4.2 & 55.3 & 45.8 & 0.0 & 0.0 & 5.1 & 190 \\
\hline Tripura & 27.1 & 22.1 & 7.1 & 26.8 & 48.1 & 1.3 & 1.3 & 9.0 & 343 \\
\hline Northeast & 41.9 & 15.9 & 8.4 & 19.0 & 37.7 & 0.3 & 0.5 & 8.3 & 5,787 \\
\hline India* & 46.8 & 13.1 & 9.2 & 24.8 & 57.7 & -- & -- & 3.9 & -- \\
\hline
\end{tabular}

* NFHS-3 report 
Indonesian Journal of Geography, Vol. 47 No. 1, June 2015 : 52 - 59

Table. 5 Composite index of reasons for not availing healthcare service from govt. health centres by states

\begin{tabular}{lrrrrrrr}
\hline States & \multicolumn{9}{c}{ Number of reasons } \\
\cline { 2 - 8 } & 1 & 2 & 3 & 4 & 5 & \multicolumn{2}{c}{ Cases } \\
\hline Arunachal & 64.0 & 30.5 & 3.6 & 1.5 & 0.4 & 277 \\
Assam & 80.6 & 16.7 & 2.3 & 0.3 & -- & 1,290 \\
Manipur & 67.9 & 27.3 & 4.2 & 0.3 & 0.4 & 781 \\
Meghalaya & 78.7 & 16.8 & 3.3 & 1.2 & -- & 739 \\
Mizoram & 89.2 & 10.8 & -- & -- & -- & 140 \\
Nagaland & 73.5 & 21.9 & 3.2 & 0.6 & 0.9 & 2,027 \\
Sikkim & 66.3 & 30.5 & 3.2 & -- & -- & 190 \\
Tripura & 65.8 & 27.1 & 5.9 & 1.2 & -- & 343 \\
Northeast & 75.1 & 20.8 & 3.2 & 0.6 & 0.3 & 5,787 \\
\hline
\end{tabular}

\section{References}

Ahmed, S.M; Tomson, Goran; Petzold, Max and Kabir Zarina Nahar (2005), Socio-economic status overrides age and gender in determining healthseeking behaviour in rural Bangladesh. Bulletin of the World Health Organization, Vol. 83(2): 109117.

Bijukumar, V. (2013), Social Exclusion and Ethnicity in Northeast India. The NEHU Journal, Vol. XI (2): 19-35

Bisai, S; Saha, Kalyan B.; Sharma, Ravendra K; Muniyandi, M. and Singh, Neeru (2014), An overview of tribal population in India. Tribal Health Bulletin, Vol. 20 (Special Issue).

http://www.censusindia.gov.in/2011-prov-results/ prov_results_paper1_india.html

Chin, V. Y. W. and Noor, Azlan Mohd Noor (2014), Sociocultural determinants of health and illness: A theoretical inquiry. GEOGRAFIA OnlineTM Malaysian Journal of Society and Space, Vol. 10 (1): $49-59$.

Fomba S, Yang Y, Hua Z, Liu Q, Xiao PM. Patient's Utilization and Perception of the Quality of Curative care in Community health Centers of the Fifth Commune of Bamako. Indian Journal of Community Medicine, Vol. 35(2): 256-261.

Government of India (2011), Human Development Report of North East States 2011. Ministry of Development of North Eastern Region, New Delhi.

International Institute for Population Sciences (IIPS) and Macro International (2007), National Family Health Survey (NFHS-3), 2005- 06: India: Volume I. Mumbai, IIPS.

Jain, M; Nandan, D and Misra, S K (2006), Qualitative Assessment of Health Seeking Behaviour and Perceptions Regarding Quality of Health Care Services among Rural Community of District Agra. Indian Journal of Community Medicine Vol. 31(3): 140-44.
Keith, T. (2004), Health promotion, health education and the public health. Oxford Textbook of Public Health (Fourth Edition), Oxford University Press.

Narzary, P. K. (2012), Perceived Constraints among Adolescent Girls in Accessing Health Care in Assam, India. International Journal of Public Health Research, Vol. 2 (1): 55-64.

Narzary, P. K. and Narzary, Birphung (2005), Treatment Seeking Behaviour of Tuberculosis Among Boro Tribe in India. Stud. Tribes Tribals, 3(2): 129-132.

NEDFi (2014), http://databank.nedfi.com/content/ general-information (accessed on 15.05. 2014).

Neelima, A and Reddy, A S. (2006), People's perspectives on health care services in rural Andhra Pradesh: An epidemiologic study. Social Change, Vol. 39 (2): 257- 269.

Pandey, N (2011), Perceived Barriers to Utilization of Maternal Health and Child Health Services: Qualitative Insights from Rural Uttar Pradesh, India. Paper for oral presentation at Annual conference of Population Association of America 2011. http://paa2011.princeton.edu/download. as px?submissionId $=111751$ (Accessed on 03/05/2011).

Patel PB, Trivedi KN, Nayak SN and Patel Priyanka (2010), Health seeking behaviour of peri-urban community of Chandkheda. National Journal of Community Medicine, Vol. 1 (1): 35-36.

Singh, A; Mukherjee, Saradiya and Chandra, Rakesh (2012), Inter-district variation in socio-economic inequalities in maternal healthcare utilisation in rural Assam, 2007-08. Journal of North East India Studies, Vol. 2 (2) : 94-103.

Sundararajan, R; Kalkonde, Yogeshwar; Gokhale, Charuta; Greenough, P. Gregg and Bang, Abhay (2013), Barriers to Malaria Control among Marginalized Tribal Communities: A Qualitative Study. PLOS ONE, Vol. 8 (12). 